\section{God hjelp mot utbrenthet}

\author{
Rådgivning kan bidra til mindre utbrenthet blant leger. Det viser en \\ norsk studie.
}

Legers psykiske helse har betydning for legene selv og deres nærmeste og for pasientbehandling og arbeidsfungering. Forebyggende tilbud anbefales fordi leger, både i Norge og internasjonalt, har høyere forekomst av selvmordsatferd og sannsynligvis også utbrenthet enn sammenliknbare grupper. Leger oppsøker også hjelpeapparatet senere i sykdomsforløpet og antakelig i mindre grad enn andre. Ressurssenter for helsepersonell Villa Sana ved Modum Bad tilbyr rådgivning og gruppebaserte ukeskurs, der målsettingen er å motivere til erkjennelse av og refleksjon over livssituasjon og egne behov.

Effekten av forebyggende tiltak blant leger er lite undersøkt. I en ny studie har norske forskere kartlagt hvordan psykisk belastning, jobbstress og grad av utbrenthet endret seg fra før intervensjonen til ett år etterpå (1). Faktorer som var assosiert med og predikerte disse endringene ble undersøkt.

227 leger som kom til Villa Sana i perioden august 2003-juli 2005 samtykket i å delta i studien. 185 av disse (81\%) 88 menn og 97 kvinner - responderte ved ettårsoppfølgingen.

- Fra å rapportere betydelig høyere grad av belastning enn norske leger generelt ved intervensjonsstart var belastningsmålene signifikant redusert etter ett år. Utbrenthet og jobbstress falt til omtrent samme nivå som for norske leger generelt, sier førsteforfatter Karin Rø ved Modum Bad.

- Legene rapporterte om økt midlertidig sykefravær etter intervensjonen, men liten grad av sykmelding ved oppfølgingen. Det var en gjennomsnittlig arbeidstidsreduksjon

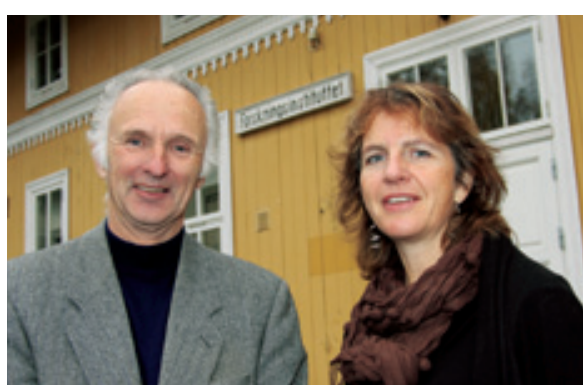

Karin Rø og Tore Gude. Foto Unni Tobiassen Lie, Modum Bad

på 1,6 timer per uke og en økning i oppsøking av psykoterapi. Reduksjon i arbeidstid var forbundet med reduksjon i emosjonell utmattelse, som er et mål på utbrenthet. Blant mannlige leger predikerte tilfredshet med intervensjonen lavere grad av utbrenthet ett år senere.

Resultatene viser at rådgivende intervensjon kan være et bidrag til mindre utbrenthet blant leger. Denne korte intervensjonen ser ut å kunne være begynnelsen på eller del av en prosess der den enkelte lege tar initiativ til viktige endringer på arbeidsplassen og i privatlivet, noe som fører til mindre utbrenthet og opprettholdelse av bedre arbeidsevne over lengre tid, sier Rø.

\section{Erlend Hem}

erlend.hem@medisin.uio.no

Tidsskriftet

\section{Litteratur \\ Rø KE, Gude T, Tyssen R et al. Counselling for burnout in Norwegian doctors: one year cohort study. BMJ 2008; 337: a2004.}

\section{Ordforklaringer}

Utbrenthet: Beskrives ofte som et begrep med tre dimensjoner: emosjonell utmattelse, depersonalisering lemosjonell distansering, en form for empatisvikt) og opplevelse av redusert personlig ytelse i jobben (1).

\section{Ressurssenteret Villa Sana ble etablert} ved inngåelse av en samarbeidsavtale med Legeforeningen i 1998. Målet var å fremme helse og livskvalitet blant helsearbeidere samt forebygge utbrenthet og styrke bevisstheten om yrkesrollen. Fra 2001 har også medlemmer av Norsk Sykepleierforbund fått tilbud om kurs og rådgivning ved Villa Sana. Totalt har 1300 leger og 700 sykepleiere benyttet seg av tilbudet siden oppstarten (2).

\section{Litteratur}

1. Falkum E. Hva er utbrenthet? Tidsskr Nor Lægeforen 2000: 120: 1122-8.

2. Lie UT. Villa Sana jubilerer. Tidsskr Nor Legeforen 2008; 128: 1881.
Er du i ferd med å publisere eller har du nylig publisert i et internasjonalt tidsskrift? Send tips til erlend.hem@medisin.uio.no www.tidsskriftet.no/norskforskning

\section{BMJ}

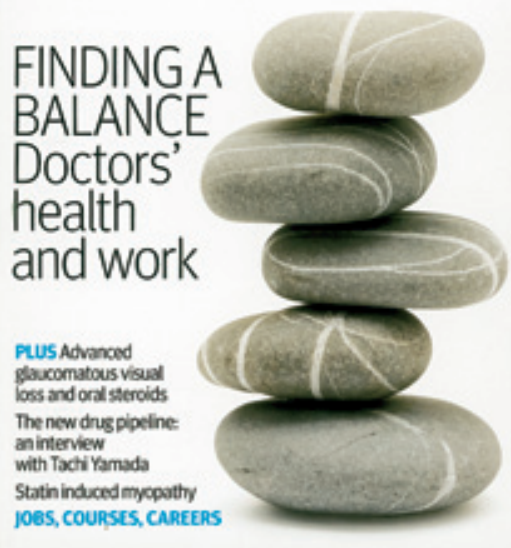

Artikkelen ble e-publisert 12.11. 2008 i BMJ, som regnes som en av de «fem store» innen medisinsk publisering, ved siden av New England Journal of Medicine, JAMA, Annals of Internal Medicine og The Lancet. Faksimile gjengitt med tillatelse 